\title{
DEVELOPMENT OF QUALITY MANAGEMENT SYSTEMS: HOW HAVE DISRUPTIVE TECHNOLOGICAL INNOVATIONS IN QUALITY MANAGEMENT AFFECTED ORGANIZATIONS?
}

\author{
DOI: 10.12776/QIP.V17I1.154
}

\author{
PASI HELLMAN, YANG LIU
}

\section{INTRODUCTION}

Quality is not a new invention in mankind's history. Although quality has been a buzz word in academic journals since 1980s, the origin of quality dates back to ancient Egyptian history. Over the years, decades and centuries there have been numerous ways to see and pursue quality. Quality movement has evolved from the master-apprentice level crafting to standardized quality system where all the processes and outcomes are measured, documented and analysed. In 1987 the International Organization for Standardization published its first quality management standards. That year marked the foundation of the first common standard for quality management and it provided guidelines what the quality management systems should contain.

Quality management systems have been developing in a rapid pace over the last century. Technological innovations in quality management systems have changed the business world and organizations have been forced to adapt to current theories or fads. In the following chapters we are going to look back at the history of quality to identify time periods and disruptive innovations in quality management. We are going to examine the three dominating quality management systems and try to predict the future of quality management. In chapter six we are explaining the effect of disruptive technological innovation and how the manufacturing in the United States failed to adapt to the new innovations. In the last chapters we will take a look at foresight methods and how the future technological innovations will affect the environment and society. The environment and society will then be reflected by the quality management systems all over the world. 


\section{QUALITY}

There are a wide variety of definitions to quality. Walter Shewhart defined quality as the goodness of product. Later this definition has been broadened to suit better both products and services. A query was conducted for numerous of manager in the United States to state their definition of quality. The following nine definitions were the most popular:

1) Perfection

2) Consistency

3) Eliminating waste

4) Speed of delivery

5) Compliance with policies and procedures

6) Providing a good, usable product

7) Doing it right the first time

8) Delighting or pleasing customers

9) Total customer service and satisfaction

(Evans 2008, pp.6)

American Society for Quality defines quality in its glossary as follows: "A subjective term for which each person or sector has its own definition. In technical usage, quality can have two meanings: (1) The characteristics of a product or service that bear on its ability to satisfy stated or implied need; (2) A product or service free of deficiencies". Several quality gurus have also their own definitions of quality. For example Dr. Joseph Juran defines quality as "fitness for use" and Philip Crosby explains quality as "conformance to requirements". Quality is usually divided to product quality and service quality. The products have physical dimensions that reflect the overall quality perceived by the customer. Service quality on the other hand is based on the experience that manifests while the service is being produced. A customer sitting in the barber's chair evaluates the received service constantly as the barbed is cutting his or her hair.

\section{QUALITY MANAGEMENT SYSTEM}

Quality management system (QMS) is a formal system that includes documenting the structure, responsibilities and processes required to achieve effective quality management. In addition, quality management is defined by American Society for Quality as follows: "The application of a quality management system in managing a process to achieve maximum customer satisfaction at the lowest overall cost to the organization while continuing to improve the process" (ASQ, 2013a).

Although there are no requirements for establishing a quality management system, a study conducted by Hendricks and Singhal's (1997, pp.1258-1274) 
evidently shows the advantages of systematic quality management. The findings include the following when comparing companies with quality management system with companies without quality management system (Shaffie and Shahbazi, 2012, pp.3):

\begin{tabular}{|l|l|l|}
\hline & $\begin{array}{l}\text { With quality } \\
\text { management system }\end{array}$ & $\begin{array}{l}\text { Without quality } \\
\text { management system }\end{array}$ \\
\hline Increase in sales & $69 \%$ & $32 \%$ \\
\hline Gain in operating revenue & $91 \%$ & $43 \%$ \\
\hline Growth in number of employees & $23 \%$ & $7 \%$ \\
\hline Increase in return on sales & $8 \%$ & Not at all \\
\hline
\end{tabular}

All the statistics show clearly that the companies with quality management system are more profitable and growing in faster pace than companies without quality management system. The study also shows that quality management system has a strong positive connection to long-term financial performance.

\section{HISTORY OF QUALITY}

The history of quality development is illustrated in Figure 1. The first signs of quality in a managed form were founded in the construction of the Great Pyramid of Giza. Scientist argue that the tools and measurement used in building the pyramids were so closely and professionally done that there had to be a systematic system for assuring the quality. Historians have also found cave painting from the Egyptian era which shows pictures of inspectors. Second clear sign of quality management was found in the Law of Hammurabi. According to Law of Hammurabi if a building falls in to pieces and the owner gets killed because of this the builder also shall be killed and if one of the owner's children is killed, one of the builder's children shall be killed. The idea behind this brutal law was to create a legislation regarding labour and product liability. In addition Law of Hammurabi contained codes concerning wages, economics transactions and agreements/contracts (Edvardsson and Gustafsson, 1999, pp.79).

Few hundred years after the Law of Hammurabi, Chou's Constitution was founded in China. Chou's Constitution contained information and laws about public administration and how the head of state controlled the government.

The most important and relevant finding from the Chou's Constitution was that it was the first systematics organizational structure that is still in use. In other words it could be named as the first quality system in fundamental level. Before the Middle Ages (500-1500) Ancient Greek era and The Roman Empire ruled the 


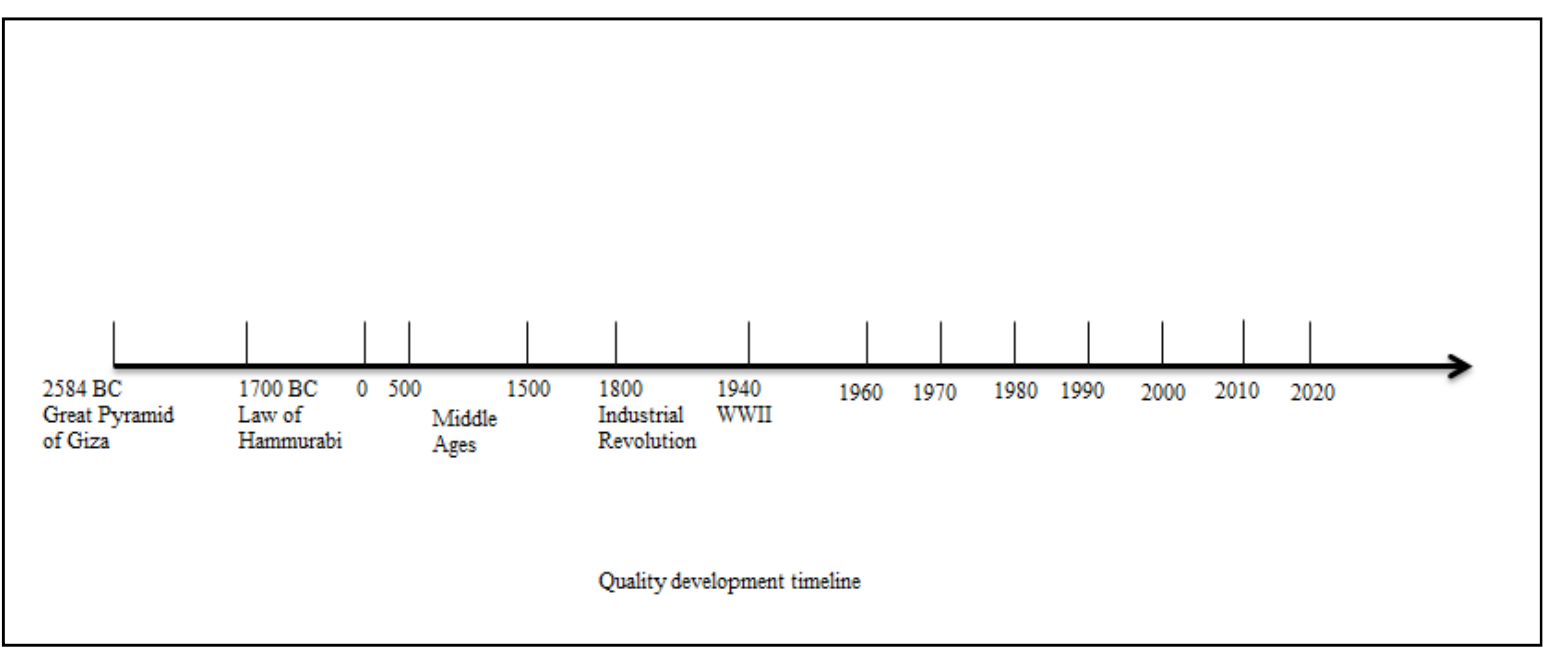

Figure 1 - Quality development timeline (Axelsson and Bergman, 1999, pp.78129)

Europe. Both were significant contributors to the modern society. Ancient Greek dedicated a lot of time to art, philosophy, authorities and justice system. The Roman Empire was the first in establishing a structured construction system.

Both Ancient Greek and The Roman Empire clearly used some kind of system to manage the quality (Edvardsson and Gustafsson, 1999, pp.80).

Years 500-1500 can be called The Age of Craftsmanship. During that period the skilled craftsmen produced a wide variety of metal, steel and leather products. A group full of craftsmen usually formed a special union called guilds. In Medieval Europe, guilds were the manufacturers and inspectors on quality. The knowledge and experience was shared in master-apprentice base meaning that the highest skilled craftsman taught the apprentice to produce and assure quality (Evans and Lindsay, 2008, pp.5).

The next important milestone in the history of quality was the Industrial Revolution. In the 1798 American Thomas Jefferson brought the concept of interchangeable part in manufacturing muskets to America. The concept was originally founded by a French gunsmith Honore Le Blanc. The concept worked very well in France where the master-apprentice mentality was still in control but when the concept was setup in America, it did not work. The most important lesson from the musket manufacturing failure was the concept of variation. Although the muskets had interchangeable parts, they needed to be almost identical in order to fit (Evans, 2008, pp.10).

In the early 1900s the United States differentiated themselves more from Europe and Frederick W. Taylor develop a new production method and management philosophy. Taylor's philosophy, also called Taylorism, concentrated on increasing the productivity without hiring new employees. The idea behind Taylorism was to divide the planning function and the production. Specialized engineers would be responsible for the planning while the craftsmen were in 
control of the production. Craftsmen were also responsible for the quality control. Failed and faulty products were simply scrapped. As the time went on the companies assigned a specific group to assure the quality. The group was autonomic and separated from the production. The creator of the modern production line system, Henry Ford, was also an influence in creating the quality system. Ford introduced the balanced assembly line which consisted of workstations with different tasks (Evans and Lindsay, 2008, pp.7).

The early $20^{\text {th }}$ century marked the birth of process thinking. The first big influence in the development of quality was Western Electric employer named Walter Shewhart. In his work, Shewhart focused on process control based on statistics. The statistics were a crucial invention in order to prevent the variation. Shewhart's goal was to control the variation by analysing the process, recognizing the cause and eliminating it from the process. He was the first to establish a simple quality improvement wheel. The stages in his wheel were specification, production and inspection. Later Shewhart moved to Bell Laboratories. While working for Bell Laboratories at Hawthorne factory he and he's co-workers realized that cold and hard management style that was base of Taylorism might not be the most efficient management style. Studies and researches at Hawthorne factor led to the establishment of HR-movement (Human Relations) (Edvardsson and Gustafsson, 1999, pp.90).

The United States military forces started to use Shawhart's invention, statistical process control, during the Second World War. In order to stay effective military, the supplies, guns and ammunitions need to be reliable and similar in quality. US Army started to require its suppliers to use SPC (statistical process control) to assure the quality. During the war US Army created the requirement which all the supplies had to meet. The MIL-STD (military standard) was the first standard that was widely used (Evans and Lindsay, 2008, pp.7). After the Second World War, the United States was the leading country in rebuilding Japan. Japan had suffered devastating losses and destruction during the Second World War. In 1945, the United States named General Douglas A. MacArthur as a leader of political, social and economic reform in Japan (USDS, 2013). General MacArthur appointed two American consultants Joseph Juran and Walter Deming to aid the rebuilding Japan (Evans and Lindsay, 2008, pp.8). Juran and Deming would later emerge as arguably the two most influential persons in the development of quality.

The year 1946 was a milestone year for quality based organizations. Three major organizations were founded in 1946: American Society for Quality (originally named American Society for Quality Control, changed in 1997), International Organization for Standardization and the Japanese Union for Scientist and Engineering. American Society for Quality (ASQ) was founded in the end of the Second World War when US experts wanted to pursue ways to continue improving quality (ASQ, 2013b). International Organization for Standardization (ISO) was founded in London when representatives from 25 countries gathered at the Institute of Civil Engineers in London, UK and decided to create a new 
organization 'to facilitate the international coordination and unification of industrial standards' (ISO, 2013b). Union of Japanese Scientists and Engineers (JUSE) was founded to promote systematic research needed for the advancement of science and technology, whereupon to contribute to the development of cultural and industry (JUSE, 2013).

1950s and 1960 were the golden age of consuming and buying goods in the United States. American consumers wanted to buy American products and factories were focused on quantity over quality. While the United States were consuming, Japan was concentrating on quality. Joseph Juran was intrigued by quality control and his efforts in Japan were a key factor in quality development. The most notable release of Dr. Juran was the book Quality Control Handbook. (ASQ, 2013c) During the same time another quality consultant, Walter Deming was making his marks on Japanese manufacturing. Deming was interested in Shewhart's statistical techniques and he later published two major quality inventions. Deming's 14 points for management is still a current topic in today's business. The other invention was the Deming Wheel. Deming Wheel consists of four steps and the idea behind the wheel is continues quality improvement. (ASQ, 2013d) 1960s was a decade of an era of many quality initiatives. Japanese Doctor Kaoro Ishikawa lectured the lower level employees about the usage of simple statistical methods. Dr. Ishikawa designed several quality tools that are used even today. They include cause-and-effect diagram (also called Ishikawa diagram), the Seven Quality tools and Quality Circles. The idea behind all the initiatives was the simpleness to use by the low level employees (Edvardsson and Gustafsson, 1999, pp.103).

In the late 1970s, quality management guru Philip Crosby published his worldknown book, Quality is Free. Crosby earned the Guru title because of his work in business and innovations. He was a great influence in changing the way organizations chase better reliability, profitability and efficiency. (ASQ, 2013e) 1980s was another remarkable milestone in the development of quality. The United States realized the threat Japan imposed because of the higher quality in products and in manufacturing. In 1987 US government named October as National Quality Month and created the Malcolm Baldrige National Quality Award (Evans, 2008, pp.12). In the same year International Organization for Standardization established ISO 9000 standard that was focused solely on quality and quality management (ISO, 2013a).

1990s saw two notable quality initiatives. In 1994 International Organization for Standardization updated its ISO 9000 quality standard to ISO 9000:1994 (ISO .2013a). In 1995 American company General Electric and its CEO Jack Welch developed their quality initiative called Six Sigma. The aim of Six Sigma is to reach a failure rate greater than 3.4 defects per million opportunities. That level of quality is called Six Sigma, hence the name. (GE, 2013) Another remarkable quality initiative invented in 1990s was called Lean Manufacturing. Fuelled by the automaker Toyota's manufacturing principles, Lean Manufacturing focuses on reducing the waste in the processes and thus making the processes as lean and 
efficient as possible (Shaffie and Shahbazi, 2013, pp.17-19). The 2000s saw two updates to the ISO 9000 standard by the International Organization for Standardization (in 2000 and 2008) (ISO, 2013a).

\section{INNOVATOR'S DILEMMA}

The main task for quality management systems is to create a systematic and controlled way to improve and assure the quality. Environment where organizations operate naturally have an effect on company's departments. That is why the main concept of quality management systems is to reflect the surrounding environment and society. The evolution of the modern society has been the biggest factor in the development of quality management systems in the $20^{\text {th }}$ century. The general level of quality has raised a lot in the last 100 years as show in Figure 2.

A good example of higher quality requirements is travelling. In the beginning of the $20^{\text {th }}$ century it was acceptable to get from London to New York in 3 days and 12 hours. Comparing that to the 7 hours it takes today, one can see a major improvement in the speed. Technology has enabled numerous of things to get faster, better and stronger. The quality management systems have been evolved hand in hand with the technological innovations. The technology that was acceptable and current in 1920s is not viable option in the $21^{\text {st }}$ century. The same goes with quality management systems. The first quality control initiatives are not enough in today's fast pace society.

The evolution of the technology called quality management system has been fairly similar to the disruptive technology model Professor Clayton Christensen presented in his innovative book 'The Innovator's Dilemma'. As Christensen writes "given the aim, technology means the processes by which an organization transforms labour, capital, materials, and information into products and services of greater value". According to the definition above the concept of technology can be extended beyond engineering and production to include marketing, financial and managerial processes. That is why quality management system can be seen as a technology. Developing technology, in other words innovation, means an improvement in any of factors above (Christensen, 2006, pp. xvi).

From the beginning of the $20^{\text {th }}$ century, one can identify seven different quality management principles. In the early $20^{\text {th }}$ century, Quality Control was the leading technology in quality management systems. The companies who used a systematic way to control and assure the quality achieved profit and growing sales. The British steel mill industry was the first to integrate a systematic Quality Control system in Europe in the 1900s. The quality management saw its first real disruptive innovation when Shewhart and his colleagues invented the Statistical Process Control. It was not enough to use Quality Control systems and the early users of Statistical Process Control achieved new levels of improvements. After the Second World War American consultant Joseph Juran 
and Walter Deming developed their models and systems for managing quality. The methods Juran and Deming developed proved to be a very disruptive quality management system and the promised country of production, the United States, was the one who suffered from the new disruptive technology.

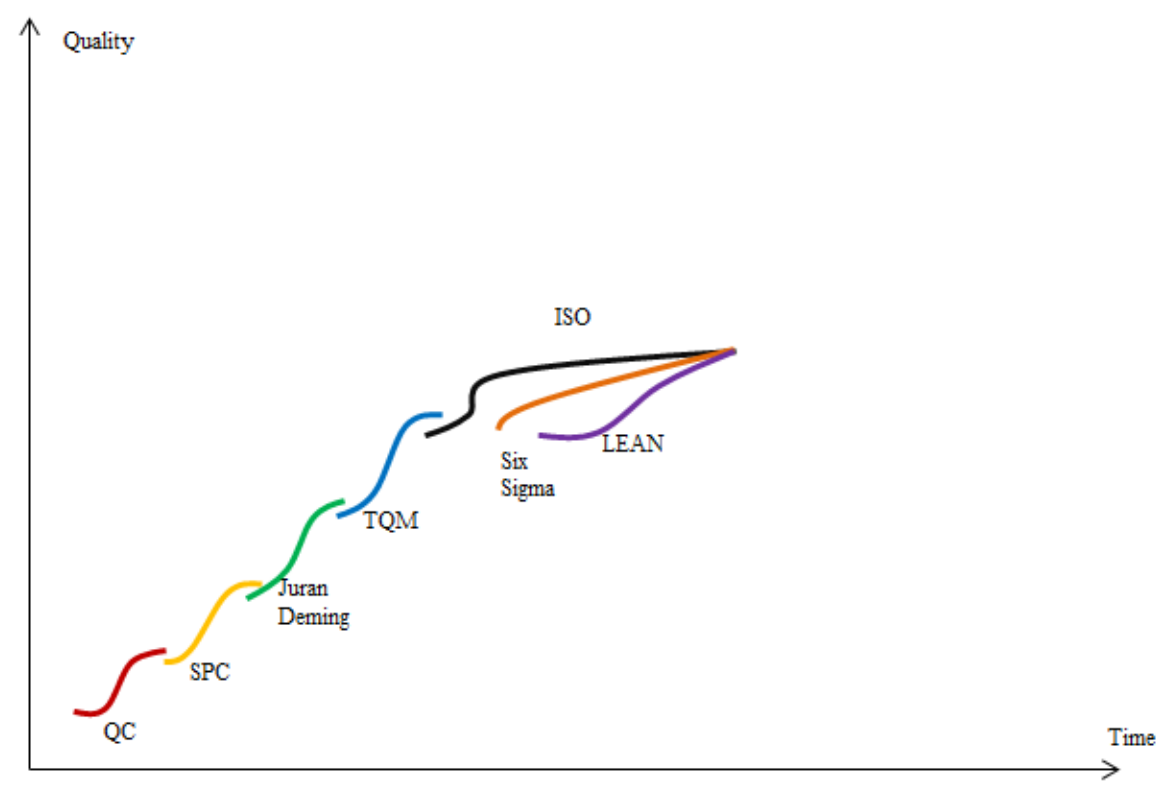

Figure 2 - Disruptive quality management system from 1900 to 2013 (Evans, 2008, pp.6-15)

After Juran and Deming had developed their frameworks to manage quality, the companies began to spread the quality management throughout the organization and departments. In the 1980s Total Quality Management (TQM) was the dominating quality management system. The quality thinking moved from the manufacturing and product-base towards organization-wide performance excellence. The Total Quality Management-movement remained as a dominant system until the mid-1990s. In the 2010s the term used is not TQM anymore. Quality has been integrated to every function of the company and there are no reasons to keep the quality in separate department (Evans, 2008, pp.13). Total Quality Management managed to combine all the best practices of the former quality management systems (Quality Control, Statistical Process Control and Juran's and Deming's teachings).

\subsection{ISO 9000}

One reason for the disappearance of the Total Quality Management is the next disruptive technology. In 1987 the International Organization for Standardization published its first Quality Management standards, ISO 9000. The purpose of the ISO 9000 Quality Management standard was to provide guidance and tools for 
companies and organizations who want to ensure that their products and services consistently meet customer's requirements and that quality is improved consistently (ISO, 2013b).

\subsection{Six Sigma}

In 1995 the American company General Electric and its CEO Jack Welch develop their version of quality management system called Six Sigma. Six Sigma is based on statistical measurement and data analysis. The three main target areas in Six Sigma are:

- Reducing defects

- Reducing cycle time

- Improving customer satisfaction

One might call Six Sigma just a combination of TQM and Statistical Process Control. Six Sigma starts first and foremost from the customer. The idea is to use statistical measures to analyse the process or product (Holpp and Pande, 2002, pp.7). There have been many process improvement models over the years but the most popular has been the Deming Wheel. Plan-Do-Check-Act wheel has been proven to be one of the most effective process development tools. Six Sigma relies on the slightly similar idea, Define-Measure-Analyze-Improve-Control (DMAIC) (Cavanagh, et al., 2000, pp.37).

\subsection{Lean manufacturing}

The very first person using Lean manufacturing method was American Henry Ford who invented the first modern production line. The idea behind the production line was to minimize all the waste in the car manufacturing process, as Mr. Ford said: "We will not put into our establishment anything that is useless". There are numerous of techniques and tools using the lean manufacturing but the main idea is always the same: to make the processes waste-free. William Levinson and Raymond Rerick have identified seven different types of waste (Levinson and Rerick, 2002, pp.38):

1) Overproduction

2) Waiting, time in queue

3) Transportation

4) Non-value-adding processes

5) Inventory

6) Motion

7) Costs of quality: scrap, rework and inspection 


\section{THE FALL OF US MANUFACTURING IN THE 1970'S AND 1980'S}

After the Second World War, every country involved suffered from the shortage of goods. Due to the size advantages the United States was able to start producing large quantities of every kind of goods. The United States was the leading country in manufacturing for decades. The top management made the decision to chase quantity over quality (Evans and Lindsay, 2008, pp.7).

The situation in the US manufacturing in the 1940s and 1950s is the prime example of the "Innovator's Dilemma". As the United States continued to response to consumer's requirements by making more and more goods, Juran and Deming kept rebuilding the Japanese economy. The base of Japanese manufacturing was quality. In business wise it made perfect sense to keep producing large quantities of products to satisfy the customer's needs. 20 years later that same decision turned against the United States as Japan took over the manufacturing domination. Like Christensen explained in his book "The Innovator's Dilemma", sounds and logic decisions by the top management were actually the reasons why US manufacturing fell so dramatically 20 years after its domination. Why did the United States fail to see the important change in the technology called quality management? The first reason was the great demand of products. Consumers demanded quantity over quality. The US companies were held captive by their customers (Christensen, 2006, pp.19).

The biggest factor to the process of falling was managerial decision making and disruptive technological change. The producers in the United States had the resources and knowledge needed to be profitable and more efficient. The disruptive technology process is explained through six steps originally used by Professor Clayton Christensen when he was analysing the rise of disruptive technology in the disk drive industry (Christensen, 2006, pp.49). The following steps occurred in the disk drive industry but they are transformed to fit the development of quality management.

Step 1: Disruptive technologies were first developed within established firms

The creators of the disruptive technology, Joseph Juran and Walter Deming, had both had a successful career in the United States before they were sent to Japan. Yet it was not before they got the recognition in Japan when top level managers started to pay attention to their teaching (ASQ, 2013d).

Step 2: Marketing personnel then sought reactions from their lead customers

The demand for consumer goods in the United States was so sizable that the factories were pushing out finished products in fast pace. The sense of pride when consuming American made products was also a key factor during that time. The nation had just started to arise as a leading country in the world and the national pride was high. 
Step 3: Established firms step up the pace of sustaining technological development

In spite of focusing on the quality management and assurance of the products, the US manufacturing concentrated on the pace of the manufacturing. The improvements in the manufacturing were mainly concerning the flow on the production.

Step 4: New companies were formed, and markets for the disruptive technologies were found by trial and error

In course of years the researchers along with Juran and Deming develop the new quality management system. The research lasted for years and it started within companies in smaller markets just like in the disk drive industry. The trial and error in the development of quality management system refers more to the extensive research than to the actual try and fail procedure.

Step 5: The entrants moved upmarket

In the 1970s and 1980s the Japanese companies started to find their ways to the US markets. Due to the cheaper prices and higher quality, the Japanese products began to eat the markets formerly ruled by US manufacturers. The strong national pride was not as effective anymore and consumers accepted goods from other countries. The high quality and low cost attracted many and within few years the Japanese products had established a steady market segments in many industries.

Step 6: Established firms belatedly jumped on the bandwagon to defend their customer base

The US manufacturers realized the potential threat the Japanese companies imposed but were unable to respond in time. The attempt to bringing down the costs led to fall of the overall quality which was followed by even greater success of the Japanese companies. This was one of the main reasons why the US automakers struggled to stay in business in the early 2000s. The bad quality mixed with high costs drove many automakers to the brink of the bankruptcy.

The other reason that caused US manufacturing to fall can be found in Christensen's RPV - framework (Resources, Processes and Values). The United States of American had all the required resources but the problem was the allocation of the processes. While the Japanese manufacturing allocated its resources to improve the quality, Americans allocated their resources to improve the quantity. In addition to the resource allocation issue, the US manufacturers were unable to create the processes needed to improve the quality and quantity. The third category in the RPV - framework defines how the decisions are made and what the priorities are. The RPV - framework does not affect only a single company or organization but it concerns the whole society or environment. In the case of US manufacturers the top level decision maker was the US government. The whole framework starts with the top level management and their decisions. 
If the president of the United States makes a decision that the nation will concentrate on the quantity, the command falls down all the way to the company owners and single managers who tell the employees what to do (Christensen 2006, pp.186-188).

\section{STATE OF QUALITY MANAGEMENT SYSTEMS}

Quality has become more and more popular over the last decade and nearly every organization has to declare its position concerning the quality. The tough economic and competitive markets have made organizations to turn their attention to the quality. Arguably the three most used quality management systems at the moment are ISO 9000, Six Sigma and Lean manufacturing. The three quality management systems differ from the methods but also from their diffusions. Six Sigma and Lean manufacturing were founded by Motorola and Toyota respectively. ISO 9000 however was founded by a group of engineering experts.

It can be said that Six Sigma and Lean manufacturing belong to Rational Efficiency- category. According to Rational Efficiency "the more organizations adopt an innovation, the more knowledge about the innovation's true efficiency is disseminated" (Abrahamson and Rosenkopf, 1990). The two quality management systems are established in the 1980s but it wasn't until 1995 when more companies started to implement the systems. General Electric and its CEO Jack Welch implemented and developed Six Sigma to fit their company and to improve their processes. Lean manufacturing was originated by Japanese automaker Toyota and later its production principles have been implemented in numerous of organizations in various industries.

ISO 9000 quality management standards were developed to create unity and to clarify the process of setting up a formal way to manage quality. After fulfilling the quality requirements, the International Organization for Standardization grants a certification to the organization. By achieving the certificate, the organization can show its customers and competitors that it has a formal quality management system. Although the idea behind the quality standards was to make it easy for everyone to improve quality in a systematic way, it was blossom some unwanted phenomenon. ISO 9000 can therefore be categorized in fad theories. Fad theory means that "the sheer number of adopters creates 'bandwagon pressures" (Abrahamson and Rosenkopf, 1990). Customers or suppliers can pressure the organizations towards applying for ISO 9000 certification. In these cases, the base of managing quality is fictitious. The same situation can occur when the market demands for ISO 9000 certification. Unless the desire for certification starts within an organization, one could question whether the quality management is either understood or wanted. 


\section{FORESIGHT METHODS}

It is very difficult to predict what kind of changes the future will hold. Quality management systems are made to reflect the society and environment and it is a fair assumption that the trend will continue. We have seen many monumental changes including the industrial revolution, the Second World War and the computerization of the world. Different trends and movements affect the society as well. For example the hippie movement in the early 1960s and the 'Green initiatives' in the 2000s have changed the society.

The main reason for using foresight methods is to explore and analyse how the future might develop and how to be prepared for it. There are several foresight methods available and when analysing technological innovations, it is a good idea to use some of them. Organizations dealing with the difficulties of technological foresight will benefit from using foresight methods in many ways. The most popular benefits are increasing the transparency of inputs, processes and outputs, aiding the visualization of possible or desirable future scenarios and making the foresight process more systematic (UNIDO, 2005, pp.116).

Foresight methods can be categorized according to their characteristics. The first distinction is exploratory methods and normative methods. Exploratory methods start with the present day and move to the future. The main question in the exploratory methods is "what if?" Past data, trends and dynamics are analysed in exploratory methods and the future is drawn according to them. Normative methods on the other hand start from the future and move backwards to present day. These methods are used to analyse how the future events might be avoided or achieved. The easiest example of the normative method is to create 'a success scenario' where one tries to identify required steps to reach the wanted scenario (UNIDO, 2005, pp.117).

The second distinction is between qualitative methods and quantitative methods. Qualitative methods are used when the accurate data is not available and the assumptions are made with simplified indicators. Brainstorming and mindmapping are examples of qualitative methods. Quantitative methods rely heavily on the numerical data. Although the data is available, quantitative methods lack the analytical part including the social and political factors. Both quantitative and qualitative methods are used together to find the most favourable mix for technological foresight (UNIDO, 2005, pp.117).

The third distinction is based on the source of the information. The two techniques are expert-based techniques and assumption-based techniques. Expert-based techniques are carried out from the informed opinions of the experts and from the clear non-questionable data. Assumption-based techniques are more based on visions and predictions. It would be easy to determine that the expert-base techniques are always better since the predictions have a reliable source, but the history has shown that either of the techniques can be proved right (UNIDO, 2005, pp.119). 


\subsection{Future of quality management systems}

Based on the current quality management systems and the available history, one can only present an obscure estimate of the future of quality management systems. The main three quality management systems (ISO 9000, Six Sigma and Lean) will most likely keep developing in a sustaining way. As history of ISO 9000 quality management standards has shown, more industries will get their specific standards and managing the quality will be more homogeneous. Both Six Sigma and Lean manufacturing have been developed in the same way. One of the emerging trends is to merge the different quality management systems in order to achieve the benefits from the each system (standardization from ISO, reducing the variation from Six Sigma and eliminating the waste in the processes from Lean manufacturing). The experts agree that new industries will be covered by the quality movement in the future. Health care is one of the newest additions and arguably the most important industry at the moment. Numerous of countries are struggling with the rising health care costs. It has been mentioned that the quality management in government might be the next point of interest. The other major development in the society has been the structural change. Before the Industrial Revolution, farmers and producers exchanged goods and services. The Industrial Revolution changed the way the world did business. The years from 1900 to 1970 were the golden years of production. The latest development has increased the portion of services in the society. The experts say the development towards service-based society has already been manifesting and due to the more and more computerized societies, the next develop might be towards the Information Technology societies. The quality requirements and quality expectations of the Information Technology society will be drastically different that the ones in the early 2010 s.

\section{CONCLUSION}

Quality movement started as early as in the ancient Egyptian era and it has evolved ever since. The most profound idea behind quality management is that it always reflects the surrounding society and environment. Changes in those factors develop the business world as well as quality management. From the beginning of the 20th century experts can identify seven different technological innovations in quality management. The seven monumental innovations of quality management have been disruptive since organizations who failed to adopt the new technology suffered. One of the most remarkable examples is the manufacturing in the United States of American in the 1970s and 1980s. The leading nation in production failed to foresight the future trends the new customers desired. Instead of responding to the treat the Japanese manufacturing imposed, the American manufacturing continued to concentrate on the quantity instead of quality. The failure of the technological leader is the same Clayton Christensen presented in his book "the Innovator's Dilemma". The innovator's dilemma can be seen everywhere in business world and in every aspect of life. 
While ISO 9000, Six Sigma and Lean manufacturing are the current dominating quality management systems, it remains to be seen how the quality management will evolve and develop in the future. The sustaining development will continue to occur but the next disruptive innovation is still in unforeseeable future. As the world continues to shift towards service-based societies, it can be predicted that the role of information technology will continue to increase. The futuristic predictions of fully computerized houses and vehicles might not be totally unrealistic. Next generation of society will also have its own quality management systems since the environment and society always dictates the usage of quality management systems.

\section{REFERENCES}

Abrahamson, E., Rosenkopf, L., 1990. When do bandwagon diffusion roll? How far do they go? And when do they roll backwards? Academy of Management: Best Paper Proceeding.

ASQ, 2013a. Glossary: Q. American Society for Quality. Available at: <http://asq.org/glossary/q.html> [Accessed 18 April 2013].

ASQ, 2013b. ASQ History. American Society for Quality. Available at: <http://asq.org/about-asq/who-we-are/history.html> [Accessed 18 April 2013].

ASQ, 2013e. Bio Philip Crosby. American Society for Quality. Available at: <http://asq.org/about-asq/who-we-are/bio_crosby.html> [Accessed 18 April 2013].

ASQ, 2013d. Bio Walter Deming. American Society for Quality. Available at: <http://asq.org/about-asq/who-we-are/bio_deming.html> [Accessed 18 April 2013].

ASQ, 2013c. Bio Joseph Juran. American Society for Quality. Available at:<http://asq.org/about-asq/who-we-are/bio_juran.html> [Accessed 18 April 2013].

Axelsson, J., and Bergman, B., 1999. The dynamics of quality and work life improvement - the Scandinavian heritage. The Nordic School of Quality Management. Lund: Studentlitteratur.

Cavanagh, R. R., Neuman, R. P., Pande, P. S., 2000. The Six Sigma Way. McGraw-Hill.

Christensen, C. M., 2006. The Innovator's Dilemma. First Collins Business Essentials.

Edvardsson, B., Gustafsson, A., 1999. The Nordic School of Quality Management. Studentlitteratur.

Evans, J. R., 2008. Quality and Performance Excellence: Management, Organization, and Strategy. Mason, Ohio: Thomson Business and Economics. 
Evans, J. R., Lindsay, W. M., 2008. Managing for Quality and Performance Excellence. Mason, Ohio: Thomson Business and Economics.

GE, 2013. What Is Six Sigma? General Electric. Available at: <http://www.ge.com/en/company/companyinfo/quality/whatis.htm> [Accessed 23 April 2013].

Hendricks, K. B., Singhal, V. R., 1997. Does Implementing an Effective TQM Program Actually Improve Operating Performance? Empirical Evidence from Firms That Have Won Quality Awards. Management Science, 43(9), pp.12581274.

Holpp, L., Pande, P., 2002. What is Six Sigma? McGraw-Hill.

ISO, 2013a. The ISO story. International Organization for Standardization. Available at: <http://www.iso.org/iso/home/about/the_iso_story.htm\#12> [Accessed 24 April 2013].

ISO, 2013b. ISO 9000 Quality management. International Organization for Standardization, 2013.2 Available at: <http://www.iso.org/iso/home/standards/management-standards/iso_9000.htm> [Accessed 24 April 2013].

Levinson, W. A., Rerick, R. A., 2002. Lean Enterprise: A Synergistic Approach to Minimizing Waste. ASQ Quality Press.

Shaffie, S., Shahbazi, S., 2012. Lean Six Sigma. McGraw-Hill.

JUSE, 2013. Outline of JUSE. Union of Japanese Scientists and Engineers. Available at: <http://www.juse.or.jp/e/profile/39/> [Accessed 27 April 2013].

UNIDO, 2005. Technology foresight manual. Organization and Methods, Volume 1. Vienna, Austria: United Nations Industrial Development Organization.

U.S. Department of State, Office of the Historian, 2013. Occupation and Reconstruction of Japan, 1945-52, Available at: <http://history.state.gov/milestones/1945-1952/JapanReconstruction> [Accessed 28 April 2013].

\section{ABOUT THE AUTHORS}

Pasi Hellman is currently a master student at the Department of Production, University of Vaasa, Vaasa, Finland; email: pasi.hellman@gmail.com.

Yang Liu (D.Sc.) is currently working as university lecturer (acting professor) at the Department of Production, University of Vaasa, Vaasa, Finland. He is the advisor and corresponding author of this paper; email: yang.liu@uva.fi. 